\title{
The Iceman Cometh by Eugene O'Neill and Chinese Thoughts
}

\author{
Xincun Huo ${ }^{1 *}$ \\ ${ }^{1}$ School School of Humanities, Arts and Education, Shandong Xiehe University, Jinan, Shandong 250109, China \\ *Corresponding author.Email: huoxincun@163.com
}

\begin{abstract}
\section{INTRODUCTION}

The Iceman Cometh, written in 1939, is regarded as a masterpiece of O'Neill, which embodies O'Neill's later understanding of life and its significance. The work, filled with despair and betrayal, fantasy and death, truly portrays the psychological damages to the people abandoned by the society. It reflects the disillusionment of O'Neill's ideal of life in the exploration of the meaning of life and in the pursuit of inner peace. The hue of the drama is dirty, crowded and dim. Most of the characters in the whole play are 50 or 60 years old. In the eyes of the Chinese people, this is an age of understanding fate and obedience. The moral of Ice is that it makes people awake, but melts in a flash, and the whole life is like a dream.
\end{abstract}

In The Iceman Cometh by Eugene O'Neill, alcohol, death, pipe dream and inner peace are the key words that appear frequently, which reflects O'Neill's mindset of self-exploration in the face of social and psychological conflicts. Pipe dream is closely related to the Taoist idea that life is like a dream. Other Taoist ideas such as unity of opposites, transcendence is also shown in the drama. O'Neill's attitude towards death is also highly consistent with the Zen view on life and death. Besides, ideas of anarchism and socialism are intertwined and collided violently, which reflects O'Neill's attitude towards the communists. Inquiry into these elements will help us form a complete understanding of O'Neill and deepen our understanding in his Chinese complex.

Keywords: Eugene O'Neill, The Iceman Cometh, Chinese thought

\section{Pipe dream and Taoist}

In The Iceman Cometh, pipe dream has appeared 36 times, mainly focusing on the relationship between pipe dream and death, anarchist movement, inner satisfaction, and alcohol. Even the saloon itself is called the Palace of Pipe Dreams. Pipe dream in this drama, like alcohol, has become an essential means to prevent soberness and intoxicate oneself as well as the ultimate way to avoid career failure and death, and to obtain inner satisfaction and peace.

In this play, everyone has a pipe dream. "The lie of a pipe dream is what gives life to the whole misbegotten mad lot of us, drunk or sober"[1]. It seems to be the only purpose for all the characters to continue the living. However, they have different pipe dreams: anarchists Larry and Hugo's is the success of the anarchist movement; the pub owner Hope's is to run for election; Joe's is to start a new casino to make money; Clara's is to get married on the farm; Hickey's is to save everyone from pipe dreams and try to awaken them. But they share the similar outcome that everyone's pipe dream cannot be realized and all of them are disillusioned in despair. Ironically, Hickey, the man who encouraged everyone to abandon the pipe dream, also went to destruction after telling the truth about killing his wife. For Larry, the cause of anarchism has become a pipe dream, and his motivation for struggle has been lost. For Parritt, due to his disillusionment with anarchism, he betrayed his mother, and thus he lived in guilt. He once used pipe dream as an excuse to shirk responsibility and reduce guilt but in vain and finally he killed himself.

The role of pipe dream. The purpose of drunkenness is to sleep, and the purpose of pipe dream is to seek inner peace. Both of them have the same effect. When Joe talked about his drunkenness, he said "'"an, when I don't want a drink, you call de morgue, tell dem come take Joe's body away, 'cause he's sure enuf dead [1]. Larry commented on the people in the saloon "They manage to get drunk, by hook or crook, and keep their pipe dreams, and that's all they ask of life. I've never known more contented men"[1]. Real peace transcends life and death and is always put together with pipe dream,and it seems that only pipe dream can bring a temporary moment of peace.

The nature of pipe dream. The place of engendering pipe dream is Hope's saloon, a place where Larry thinks the last harbor and as harmless as a graveyard [1]. The Iceman Cometh is a tragedy, originally a joke, but in the end we can't laugh facing the cruel reality. The dream bubbles finally burst into nothing. Larry, a wise man, lost the game. Parritt's mother, a supporter and leader of the movement, was betrayed by her son, Parritt, who killed himself in guilt for betraying his mother. Hickey, a romantic man deeply loved by his wife, also faces death penalty. Only Larry is alive, but he is in agony, just because he has no courage to die despite the fact in career failure and lover's degeneration and he can't be really relieved, and be detached. 
Real peace means inner contentment and satisfaction, which can not be gained by pipe dreams and alcohol. Larry's real cause for unease is the guilt for his wife while that of Parritt's unease comes from his debt to his mother. What they really lack is the peace in conscience. Larry doesn't want others, especially those once in the movement to disturb his peace, because the disillusionment of his dream in the movement is cruel to anyone. They all lack real peace because of desires, or guilt, or troubles. Hickey said he came to see the guys to save them and bring them real peace. After the collapse of the anarchist movement, Larry " hoped I'd found a place of retirement here where no one in the Movement would ever come to disturb my peace" [1]. According to Hickey, "I finally had the guts to face myself and throw overboard the damned lying pipe dream that had been making me miserable, and do what I had to do for the happiness of all concerned--and then all at once I found I was at peace with myself and I didn't need booze any more. " [1] ". So Hickey wants to wake up the people sleeping in pipe dreams. However, his own life is so much like a dream. Facing his beloved wife, he bears too much emotional debt and has no way to repay it. In the end, he can only end it by killing his wife with his own hands, which means the end of his own life. Hickey once said, "I couldn't give you my peace. You've got to find your own. "[1]. But he also has nowhere to find his own inner peace, although he had tried to find it through encouraging others to find their peace. The elements of Taoist thought reflected in the drama resulted from the despair of reality: the betrayal of kinship, the degeneration of lover and the failure of career. In disappointment, what they can only rely on is alcohol and pipe dream to evade the conflict of thoughts, which lead them to turning to Taoism in solving the reality problems: Anything is born out of nothing. Once something exists, no matter how gorgeous, will go to nothing.

Dream has always been one of the main manifestations of Taoist thought, and a typical example is the household story of ZhuangZhou's Dreaming of Becoming a Butterfly. The living is a short dream, and the death is a longer dream. Life and death are but dreams. According to Zhang Guangbao[2], "Dreams obscure people and make people unable to see the truth of life. Like a wise magician, they often play tricks on superficial human rationality". People complete a shorter life cycle through sleeping in dreams and awakening, while life and death are only a relatively longer life cycle. ZhuangZhou's understanding and application of dreams are different from O'Neill's. ZhuangZhou's dream is a means to ends while O'Neill's dream is more closely related to life, death and inner peace. Li Xin[3]summarized ZhuangZhou's dream as follows:

In the fable of ZhuangZhou's dream, the mysterious and apocalyptic color has been abandoned, and it has been explicitly incorporated into the writing system as a clue connecting the story plot. Dreams are used as the medium to show the theme, such as dreams and butterflies, as well as the focus of thinking and discussion. Dreams is also regarded as a transitional form in skull dreams, which only provide a reasonable scene for the skull to speak, and dreams are only a means of connecting the plot. Dreams can also be adopted as a metaphor, such as the behavior of Confucius who is about to practice ancient laws and ridicule Confucius with nightmares in the The Revolution of Heaven. All these examples embody ZhuangZhou's unconstrained use of dreams, which plays a pioneering role in opening and playing people's imagination in literature.

In addition to pipe dream, the ideas of unity and opposites and selflessness are also shown in this work. "Honor or dishonor, faith or treachery are nothing to me but the opposites of the same stupidity which is ruler and king of life, and in the end they rot into dust in the same grave."[1], "Worst is best here, and East is West, and tomorrow is yesterday"[1], "I took a seat in the grandstand of philosophical detachment to fall asleep observing the cannibals do their death dance"[1]. These words reflect O'Neill's profound insight into dialectics, which highly agree with Taoism, and indirectly reflect the influence of Taoism on O'Neill.

Pipe dream and peace are the two most frequently used words, especially in the three and four acts. Despair and betrayal of the people in the saloon is the most sharp revelation of the degradation power in human nature.

(1) The power of despair. With Hickey's encouragement, all the people in the saloon began to have a little desire to change the status quo, but this desire was too small to survive in the cruelty of the reality for even a day. Hope, the owner of the pub hasn't been out for more than 20 years. When he finally got to the middle of the road under the instigation of Hickey again, he was too afraid to move forward. People's inertia is shown so vividly in Hope. Once people degenerate, or enter a degenerate state, it is more challenging for him to find the motivation to change. What Hickey brings is not lucidity, but emotional fluctuation, which is different from the change brought by hope and perseverance. The decadent hope is like a flash in the pan. The greatest value of dreams is not whether they can be realized, but the power to live, to make you better and improved than present.

In the narrow space in the pub, they wait for Hickey, whose arrival has become the power of change, but the change has not lasted for a long time. With Hickey being caught by the police, everything has returned to the decadent state. The inertia of despair is exerted incisively and vividly. Pipe dream and alcohol represent the rejection and resistance to change the status quo, which is a great power to block the positive energy.

(2) Betrayal. The betrayal of husband to wife and son to mother is very difficult to accept emotionally, but it happens in reality. The result for betrayal is psychological guilt and and repeated treason. Hickey had been hopelessly depraved, but his wife's forgiveness over and over again put a heavy burden on him, and even eventually he wanted to end everything. Parritt, in order to get rid of his mother's control, betrayed his mother and finally killed himself. 


\section{Death and Chinese Zen}

O'Neill's view on death is incisively and vividly expressed in the drama. The whole work is full of the smell of decay and death. A group of people who are drunk and dreaming live in a dark saloon. Hope's wife died, Parritt committed suicide after reporting her mother's guilt, and Hickey could not bear his wife's gentleness and considerateness and killed her. These are all direct deaths. While Parritt's mother was imprisoned for life, Hickey also faced the death penalty, which indirectly refers to death, because death is only a deprivation of time. And those who life are not in danger for the time being is similar to the dead.

In this work, death is mainly described by four words: dead, death and die, dying. O'Neill's relevant treatise on death is: Larry is waiting for death, but because he is afraid of death, and he has never died. Larry viewed death as a good long sleep. In the process of waiting for death, Larry cursed some people for drinking to death and watching those cannibals dance to death. Hope said that Larry always talks about death[1], which shows that Larry pays more attention to death and thinks about the ultimate value and significance of life. However, "I'm afraid to live, am I?--and even more afraid to die!"[1]. Fear of death is the instinct of life, Larry is no exception.

The conflict between Larry and Hickey on the issue of life and death can be seen as the conflict between the two contrasting views of life, especially on the meaning of life and death. "Then you'll know what real peace means, Larry, because you won't be scared of either life or death anymore"[1]. Hickey's persuasion reflects O'Neill's true meaning of peace. Savored carefully, it goes to emptiness, which shares similar pursuit with Chinese Zen, that is, to achieve immortality through practising emptiness. But O'Neill just dispels the fear of death in this life, and the purpose is not eternal life. Although the ultimate pursuit is different, the inner peace they desire to gain is the same.

In Larry's eyes, Hickey was separated from death at first, but later connected with it. "Hickey has the breath of death "[1] and "brings death"[1]. Later, Hickey became the embodiment of death. Larry is very sure that Hickey has brought death. Larry said that Hickey has the magic of awakening death [1], Hugo also said Hickey is promoting death[1]. Why did old Hickey bring kindness and joy, but present Hickey wakes up people and brings death? In the past, Hickey invited everyone to drink, spent all their money, respected the people's dreams, and people immersed themselves in joy. Now Hickey wants to wake up the people, and make them realize the situation that they are at the bottom, it is so difficult to face the immutable desperate situation of existence and death. As Lu Xun [4] once said in the preface to Call to Arms:

"If an iron room is absolutely windowless and hard to break, there are many people sleeping in it, who will soon suffocate, but will not feel the sadness of dying from sleeping to dying. Do you think it's right for you to raise your voice and rouse some of the more sober people, so that the unfortunate few may suffer from the hopeless agony of dying?"
Therefore, this kind of behavior by avoiding or denying the present world is also highly consistent with Chinese Zen thought.

In addition, Hickey himself is also a person at the bottom, a product of tragedy and inextricably linked with death. In fact, for people like him struggling at the bottom, death is perhaps a relief. However, facing the fear of death instinct, people can do nothing but continue to live.

In the drama, three characters died due to various reasons: Bessie, Parritt's mom and Hickey's wife. Hope didn't treat Bessie well when she was alive. However, when she died of illness, he was full of nostalgia. The power of death is evident. For any individual, death means the disappearance of permanent existence, as well as that of the social significance related to physical life. Parritt's mother's neglect of him due to the movement is an important reason for him to betray his mother. Parritt died of guilt for his mother. He seemed to fear nothing about death and find peace in death. But Hickey's wife, Evelyn, died of trust and forgiveness in his husband, which made Hickey too hard to repay the psychological debt and to continue living with his wife. Evelyn said that only death can break my love for you[1]while Hickey told her that when he was ready, he would marry her. The whole work shows the tragic ending of Hickey and his wife. In fact, from the perspective of Evelyn, her tragedy of death lies in her obsession with a relationship while the Chinese Zen emphasizes the importance of letting go of obsession and getting rid of one's inner obstacles.

In fact, Hickey and Parritt are both tragedies. Parritt's mother is the tragedy of the movement and the victim of the bad parent-child relationship. Hickey's wife is the victim of the bad relationship between husband and wife. Selfless love does not exist between husband and wife. Parritt's mother always said that those who lost faith in the movement should have died, which is an excuse he found for betraying his mother. In order to get rid of the mother's control and to atone for his sins, he chose to commit suicide. After Parritt's death, Hickey said painfully that he really wanted to die, who can really share Parritt's guilt.

ZhuangZhou's life realm of "never living, never dying" has something in common with "no living, no dying" in Mahayana Buddhism. Both of them tend to break the false attachment to life through the two ends of life and death. ZhuangZhou's limited life is extended to free life by melting into the endless flow of changes of Tao, in which his power is to integrate the movement of Tao; Buddhism's power is to melt life purely through the interpretation of the unreal nature of life. After the unreal life retreats, the real and constant entity follows[2]. In fact, ZhuangZhou dispels life through change, while Zen dispels fear of death through invariance. Confucianism attaches importance to the meaning of death, which encourage people give up one's life for upholding the righteousness. Taoism emphasizes the value of life, which refers to the judgment of the importance between life and fame, that is, emphasizing more on life rather than material things and fame. Confucianism sublimates the quality of life and spiritual level in the great pattern of sacrificing one's life 
for righteousness, which makes people understand death from another perspective.

\section{O'Neill's Red Imprint}

How does anarchism appear in $\mathrm{O}^{\prime}$ Neill's works? Why does it appear? Will O'Neill's disappointment with anarchism be the source of his interest in Taoism, as they share something in common on the term "nothing"? What effect does its appearance bring to works as well as the author? All these questions need to be answered by careful exploration of his works.

Anarchism and communism are inextricably linked. At the beginning of the 20th century, the early leaders of the Communist Party of China are"deeply influenced by it" [5]. O'Neill's red imprint is manifested in his contempt for the bourgeoisie, his sympathy and understanding for socialism, and his questioning of anarchism. The play fully shows O'Neill's understanding and judgment of anarchism and socialist ideas.

O'Neill called himself a philosophical anarchist. "O’Neill publicly defended anarchists and socialists and railed against racial injustice"[6]. He also has friends who believe in anarchism. There are altogether four characters belonging to anarchists: Hugo, the anarchist editor, is surprisingly clean, and has the appearance of foreign radicals, very similar to the anarchists with bombs. Larry, once an anarchist, was cynical and slovenly, but was full of ideas and kept thinking about value of life. Rosa Parritt, the leader of anarchism, also pursues the principle of anarchism in her personal life, and practices the debauchery in the name of freedom. Parritt, the son of anarchist Rosa Parritt, became angry with his mother and later felt guilty for betraying his mother.

O'Neill's attitude towards anarchism is most incisively expressed through the four roles. Hugo, once an editor of an anarchist magazine, paid a heavy price for faith and spent ten years in prison in his own country. As a supporter of the anarchist movement, he also hated the bourgeoisie, who he laughed as the little monkey face of the bourgeoisie like a fool! In the dialogue between Larry and Hugo, the two key words "revolution" and "movement" are frequently used, while Hugo uses the two terms "traitor" and "worker" as the reply, which shows Larry's rationality and Hugo's radicalism.

O'Neill's evaluation of ideal and anarchism is mainly reflected in his depiction of Larry. Larry has repeatedly stressed that he and the anarchist movement are over and he thinks that anarchist movement is just a beautiful daydream, and anarchists' silly pursuit of power. For Larry, the reality is meaningless, and the dreams are all shattered, and only hope for a good long sleep. One of the reasons he was disappointed in the anarchist movement on the west coast was reluctant to give up greed to get salvation. Larry thinks that the reason why he quit the anarchist movement is that he thinks too much. He thinks that the bricks and tiles of building a free and ideal society are people themselves, and that it is impossible to build a marble temple with mud and excrement. Therefore, anarchists must be indomitable and firm in their ideals and beliefs. Larry, as an anarchist, had to submit to the cruel reality, but still showed his thinking qualities in many aspects, which is clearly demonstrated in his evaluation of people and things. When Joe mentioned the difference on anarchists and socialists, three distinguishing characteristics are listed as whether to work, whether to pay for drinking and whether to share the money with you after earning, and he is evaluated by Larry that he has both perfect human nature and secular practical philosophy, which also showed that socialists have more positive image in O'Neill's mind. In commenting on Willie's purchase of alcohol by pawning clothes, Larry said bitterly that it was a great game in the pursuit of happiness. When Rocky bought the police for two prostitutes, Larry said he was a shrewd businessman who never let go of any chance to make money. When Hope missed his wife so much, Larry said that Hope fantasized the past as a paradise, because when Bessie was alive, he had hated Bessie. When Larry commented on the living state of Hope's saloon, he said that in the saloon, good is bad, East is west, tomorrow is yesterday, and he is against putting all hopes on tomorrow. His view of life is that death is a good sleep and bad destiny. Larry's disappointment with anarchism explicitly shows O'Neill's disappointment, which may further explains why he turn to communism.

Rosa Parritt and Larry have a solid friendship, and she even keeps their letters in the situations of extreme danger, which clearly indicates that Larry has an important position in her mind. Her zeal for the movement is like her faith and she believes whoever loses faith in the movement should die for it, because it is Judas' action and should be thrown into the oil pot. She was also disappointed with her son, because his son Parritt, who had been engaged in the movement all his life, became indifferent to it. Parritt is full of resentment for his anarchist mother, who has no time to take care of himself, limits his freedom, and sacrifice her own and his freedom for the long-term and eternal freedom of mankind. For his mother's sake, Parritt got angry with prostitutes, who were so similar with his mother in dissipated personal life. Larry said that Parritt was influenced by his mother to be fully engaged in anarchism. The education he received since childhood made him a devout follower of the movement. As the son of the anarchist leader, Parritt after betraying his mother, lost the courage to continue living in this world. From Parritt 's words, we could know that in the process of striving for the ideal, anarchists like his mother and Communists don't have enough to eat. Spiritually, anarchists are busy with their ideals and leave little time to their family. They believe in anarchy, so the first step is to take away the power of the government and obtain the ultimate freedom. In the eyes of the saloon owner Hope, anarchists are stupid and do nothing. When it comes to Larry, Hickey said he is the most difficult to persuade, because Larry has his own ideas and does not follow the rest.

At the beginning any new movement or thought, there was always the tendency of extreme behavior, which is 
necessary as no one would understand everything and if these overcorrect actions never appear, there would be no way to go back to the normal track. Philosophical anarchists maintained three chief principles: unconditional nonviolence, one-on-one instruction rather than mass propaganda, and the complete disregard of all social and political institutions as "phantasms," "ghosts," or "spooks" to exorcise from one's mind[6]. Unreasonable things will be slowly deserted with the development of society. Ironically, Parritt's mother, an anarchist of emancipation, was ashamed of emancipation. "Utopia", "women's Liberation", "faith", "prisoners of bourgeois morality and jealousy" are the label words to describe anarchists. Parritt's mother shows how open-minded she is by cohabiting with many men, so she has different lovers all year round. When she was educating her son, she even said that respecting parents is the nonsense of bourgeoisie and proprietors. In Parritt's eyes, the anarchists are fanatics, drunkards and emancipated women.

The enormous tragedy of anarchists is fully revealed in the end: the son of an anarchist leader, betrayed that great cause just for a prostitute. Parritt said he just wanted to get some money to make her happy, even for a while and he sold a large number of rap liars and cheated fools with daydreams.

\section{Conclusion}

O'Neill's thought is relatively complex and is influenced by various philosophical approaches. It has also been deeply marked by the era of 1920s and 1930s. However, there are many similarities between O'Neill's thoughts and Chinese traditional thoughts, especially his interest in Taoism, which is also reflected in his many works and real life. Present research shows that he has no clear origin with Chinese Zen, but has the same subtlety with many of its concepts, reflecting the universality of human culture. The connection of O'Neill with communism and anarchism is closely related to his personal experience and background of the times. O'Neill was inevitably influenced by anarchism and communism, which were so popular the 20 s and 30 s of the twentieth Century.

Generally speaking, O'Neill's understanding of Chinese traditional thought is very deep and systematic. He has read a lot of Chinese classics, and has also come to China to seek peace. The key words that appear frequently in The Iceman Cometh such as alcohol, death, pipe dream and inner peace are closely related to the Taoist ideas. O'Neill's attitude towards death is also highly consistent with the Zen view on life and death. Besides, ideas of anarchism and socialism are interwoven together, which reflects O'Neill's attitude towards the communists. Inquiry into these elements will help us form a complete understanding of O'Neill and deepen our understanding in his Chinese complex.

\section{ACKNOWLEDGMENT}

The paper is the phased research finding of the project A Study on Chinese Imprints in Post-war American Drama [Approval NO.:17CWZJ41], funded by Shandong Social Science Planning and Management Office.

\section{REFERENCES}

[1] E. O'Neill. O'Neill Complete Plays 1932-1943. New York: The Library of America, 1988.

[2] G.B. Zhang. The Development of Taoism in Primitive Taoism -- Metaphysical Theory of Dream and Life and Death in Taoism.History of Chinese Philosophy, 2002(03), pp96-106

[3] X.Li. The Influence of Dream Fables in Chuang Tzu and Liezi on the Creation of Ancient Dream Novels. Seeker, 2010(01), pp169-171.

[4] Lu Xun. Preface to Call to Arms. Beijing:Beijing Xinchao Press, 1923

[5] J.Y.Zhao. Chinese Marxism's Critique on Anarchism: The Cases of Mao Zedong and Yun Daiying. Modern Philosophy,2019(03),pp61-69.

[6] R. M. Dowling. Eugene O'Neill: A Life In Four Acts. New Haven and London: Yale University Press, 2014 . 